\title{
СМЕРТНОСТЬ ДЕТЕЙ ДО 1 ГОДА В РОССИИ: ЧТО \\ ИЗМЕНИЛОСЬ ПОСЛЕ ПЕРЕХОДА НА НОВЫЕ \\ ОПРЕДЕЛЕНИЯ ЖИВОРОЖДЕНИЯ И \\ МЕРТВОРОЖДЕНИЯ
}

\author{
ЕКАТЕРИНА КВАША
}

\begin{abstract}
Снижение младенческой смертности в России продолжается уже несколько десятилетий. Но достигнутый Россией в 2011 г. уровень младенческой смертности (7,4 на 1000 родившихся живыми) более чем в три раза выше, чем в странах с ее минимальными уровнями. В апреле 2012 г. Россия перешла на новые определения живо- и мертворождения, которые гораздо ближе к соответствующим определениям ВОЗ, чем использовавшиеся до этого.
\end{abstract}

Переход на эти новые определения должен был бы увеличить показатели как перинатальной и ранней неонатальной, так и младенческой смертности в изелом для детей с весом до 1000 г, которых затрагивает изменения определений.

В статье анализируются изменения в структуре и динамике смертности детей до 1 года после перехода на новые определения живо- и мертворождения в зависимости от веса новорожденного и периода смерти по данным государственной и медицинской статистики. Рассматриваются возможные искажения показателей младенческой перинатальной смертности и их компонент.

Особое внимание уделено анализу структуры младенческой смертности по возрасту и причинам смерти в России по сравнению с другими странами. Также рассматривается региональный аспект изменения младенческой смертности за 2011-2012 г2. Анализ проводится на основе данных государственной и медицинской статистики.

Ключевые слова: Мертворождаемость, ранняя неонатальная смертность, младенческая смертность, причины смерти, определения живо- и мертворождения, вес ребенка при рождении.

\section{ДОЛГОВРЕМЕННЫЕ ТЕНДЕНЦИИ МЛАДЕНЧЕСКОЙ СМЕРТНОСТИ}

Снижение смертности детей до 1 года, в отличие от других возрастных групп, идет в России уже в течение нескольких десятилетий, и это считается одним из важных достижений страны в социально-экономической и медицинской сферах. Но при более тщательном анализе выясняется, что достижения не столь значительны.

Достигнутый Россией в 2011 г. уровень младенческой смертности (7,4 на 1000 родившихся живыми) более чем в три раза выше, чем в странах с ее минимальными уровнями (в 2011 г.: 2,3\%о - Норвегия, 2,4\%о - Финляндия, Эстония [WHO 2014a]), а также существенно выше, чем в большинстве европейских стран, в том числе стран Восточной Европы.

ЕКАТЕРИНА АЛЕКСАНДРОВНА КВАША, ИНСТИТУТ ДЕМОГРАФИИ НАЦИОНАЛЬНОГО ИССЛЕДОВАТЕЛЬСКОГО УНИВЕРСИТЕТА «ВЫСШАЯ ШКОЛА ЭКОНОМИКИ». РОССИЯ. Е-MAIL: ekvasha@hse.ru.

СТАТЬЯ ПОСТУПИЛА В РЕДАКЦИЮ В АПРЕЛЕ 2014 Г.

* В СТАТЬЕ ИСПОЛЬЗОВАНЫ РЕЗУЛЬТАТЫ ИССЛЕДОВАНИЙ, ВЫПОЛНЯВШИХСЯ В РАМКАХ ПРОГРАММЫ ФУНДАМЕНТАЛЬНЫХ ИССЛЕДОВАНИЙ НИУ ВШЭ В 2013-2014 ГГ.

АВТОР ВЫРАЖАЕТ БЛАГОДАРНОСТЬ Е.М. АНДРЕЕВУ ЗА ПОМОЩЬ В ПОДГОТОВКЕ ЭТОЙ СТАТЬИ. 
В начале 1980-х годов показатели младенческой смертности в России были примерно такими же, как в европейских странах с относительно высокой младенческой смертностью (рисунок 1). К началу 2010-х годов Россия продолжает оставаться в этой достаточно компактной группе. Лишь Португалии удалось кардинально изменить свое положение. В 1980 г. в Португалии младенческая смертность была на 2,3 пункта промилле выше, чем в России, а к 2011 г. она стала на 4,2 пункта или в 2,4 раза меньше, чем в России. Болгария в 2009 г. и Украина в 2007 г. перешли на определение живорождения, соответствующее рекомендациям ВО3, и именно этим вызваны скачки показателя в этих странах. До этого в них использовалось то же определение, что и в России, а коэффициенты младенческой смертности были ниже, чем в России.

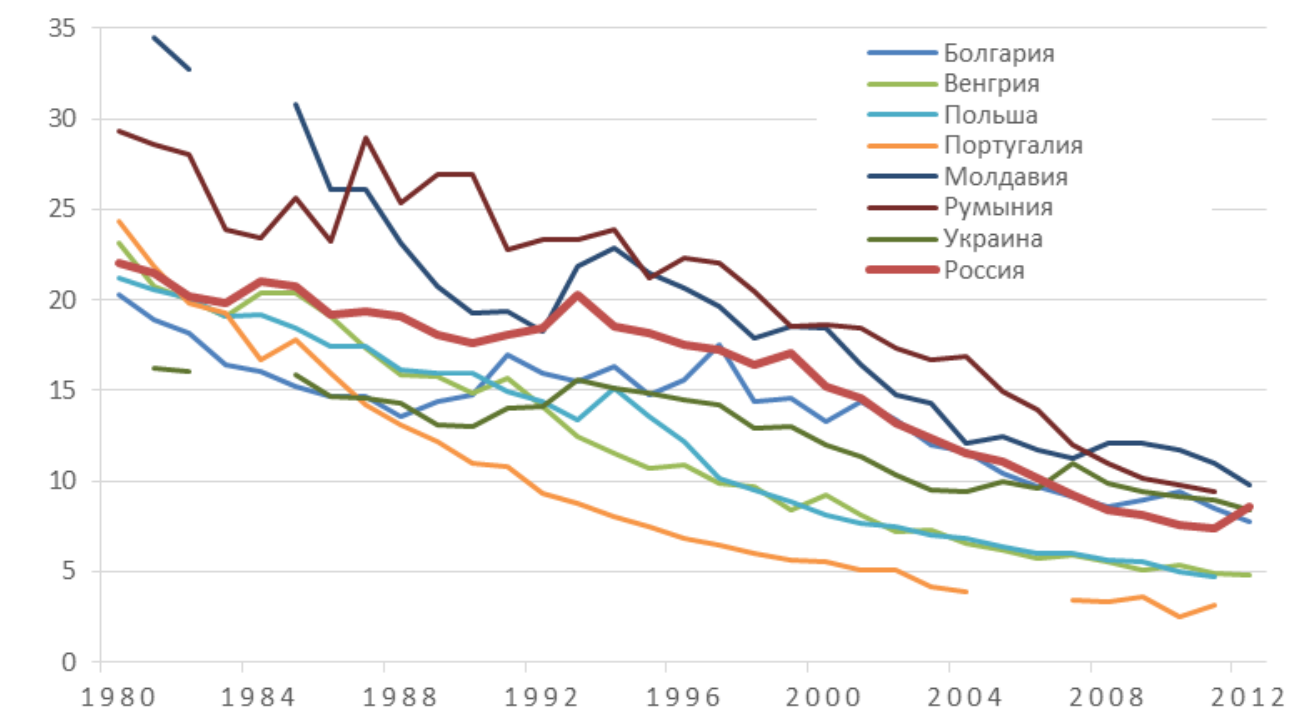

Рисунок 1. Младенческая смертность в ряде европейских стран, 1980-2012 гг., на 1000 живорождений

Источник: [WHO 2014a; Pосcтат 2013].

\section{ИЗМЕНЕНИЯ ОПРЕДЕЛЕНИЙ ЖИВО- И МЕРТВОРОЖДЕНИЙ С 2012 Г.}

В 2012 г. уровень младенческой смертности в России вырос и составил 8,6 на 1000 родившихся живыми против 7,4 в 2011 г. Такой рост показателя связан с переходом России с апреля 2012 г. на использование нового определения живорождения и был вполне предсказуем [Андреев, Кваша, Харькова 2013].

Напомним что, согласно определению ВОЗ живорождение - это полное изгнание или извлечение из организма матери продукта зачатия вне зависимости от продолжительности беременности, причем плод после такого отделения дышит или проявляет другие признаки жизни, такие как сердцебиение, пульсация пуповины или явные движения произвольной мускулатуры, независимо от того, перерезана ли пуповина и отделилась ли плацента. Ребенок, обладающий такими признаками, рассматривается как живорожденный. 
По рекомендации ВОЗ все живорожденные дети должны регистрироваться и учитываться как таковые, независимо от продолжительности беременности или от того, были ли они живыми или мертвыми в момент регистрации; если они умирают через какоето время сразу после родов, они также должны регистрироваться и учитываться в числе смертей.

В России до 1993 г. живорожденным считался ребенок, родившийся при сроке беременности 28 недель и более, с массой тела 1000 г и более, с длиной тела 35 см и более и который после рождения начал дышать. Если дети родились при меньшем сроке беременности, весе или длине тела, то они включались в число живых только в случае, если прожили 7 полных суток (168 часов).

Приказ Минздрава Российской Федерации от 04.12.1992 №318 и постановление Госкомстата России от 04.12.1992 №190, ввели в практику учета живо- и мертворождений новые критерии, аналогичные критериям ВОЗ. Но на это определение в полной мере перешла только ведомственная (медицинская) статистика. В органах ЗАГС по-прежнему регистрировались родившиеся с массой тела 1000 г и более, а если неизвестна масса тела, то с длиной тела 35 сантиметров и более и сроком беременности 28 недель и более, а также живорожденные с массой тела менее 1000 г при многоплодных родах и все родившиеся с массой тела от 500 до 999 г, если они прожили более 168 часов (т.е. 1 неделю).

Фактически, по сравнению с ситуацией до 1993 г. в число живорожденных вошли:

- $\quad$ дети, у которых отсутствовало дыхание, но имелись другие признаки жизни, такие как сердцебиение, пульсация пуповины или произвольные движения мускулатуры;

- $\quad$ дети с массой тела от 500 до 1000 г, родившиеся при многоплодных родах и умершие в ранний неонатальный период.

23 марта 2012 г. в «Российской газете» был опубликован приказ Министерства здравоохранения и социального развития Российской Федерации (Минздравсоцразвития России) от 27.12.11 №1687н "О медицинских критериях рождения, форме документа о рождении и порядке его выдачи", в котором утверждались новые критерии живо- и мертворождения. Согласно этому приказу живорождением является момент отделения плода от организма матери посредством родов при сроке беременности 22 недели и более, при массе тела новорожденного 500 г и более (или менее 500 г при многоплодных родах) или, в случае, если масса тела ребенка при рождении неизвестна, при длине тела новорожденного 25 см и более при наличии у новорожденного признаков живорождения (дыхание, сердцебиение, пульсация пуповины или произвольные движения мускулатуры независимо от того, перерезана пуповина и отделилась ли плацента). ${ }^{1}$ Приказ Минздрава России от 16.01.13 г. "О внесении изменений в приложения №1 и №3 к приказу Минздравсоцразвития РФ от 27.12.2011 г. №1687н "О медицинских критериях рождения, форме документа о рождении и порядке его выдачи" уточнил перечень медицинских критериев рождения ребенка. Он предусматривает, что критерием рождения является также

\footnotetext{
${ }^{1}$ http://www.rg.ru/2012/03/23/kriterii-rozhd-dok.html
} 
срок беременности менее 22 недель или масса тела ребенка при рождении менее 500 г, или в случае, если масса тела при рождении неизвестна, длина тела ребенка менее 25 сантиметров - при продолжительности жизни более 168 часов после рождения (7 суток $)^{2}$.

Соответственно расширились и критерии мертворождения. Согласно приказу Минздравсоцразвития России от 27.12.11 г. №1687н «Мертворождением является момент отделения плода от организма матери посредством родов при сроке беременности 22 недели и более при массе тела новорожденного 500 грамм и более (или менее 500 грамм при многоплодных родах) или в случае, если масса тела ребенка при рождении неизвестна, при длине тела новорожденного 25 см и более при отсутствии у новорожденного признаков живорождения» ${ }^{3}$.

Такое расширение критериев живо- и мертворождения приблизило Россию к соответствующим критериям ВОЗ. Однако различия еще остались. Как мы видим, в определении живорождения ВОЗ четко указано, что должны учитываться все продукты зачатия вне зависимости от продолжительности беременности и веса, а у нас остались ограничения по сроку беременности и массе тела новорожденного.

Россия - не единственная страна, где используются неполные определения живо- и мертворождения ВОЗ. Например, в Болгарии живорожденным считается ребенок, если он проявил хоть один признак жизни при весе более 600 г или сроке беременности более 22 недель. В ином случае, чтобы считаться живорожденным, он должен прожить не менее трех дней. В Чехии, кроме наличия признака жизни, чтобы считаться живорожденным, ребенок должен иметь вес более 500 г или с меньшим весом прожить 24 часа. На Украине регистрации в органах записи гражданского состояния подлежат дети, родившиеся живыми или мертвыми с весом 500 г и более или при сроке беременности 22 недели и более.

Изменение критериев живорождения привело и к изменению структуры абортов. Из них почти исчезли аборты на поздних сроках беременности. Согласно приказу Минздравсоцразвития России от 27.12.11 №1661н "О внесении изменений в Приказ Минздравсоцразвития России от 3 декабря 2007 г. № 736 "Об утверждении перечня медицинских показаний для искусственного прерывания беременности"4 аборт на сроках свыше 22 недель у детей с врожденными аномалиями (пороки развития), деформациями и хромосомными нарушениями разрешается проводить только по индивидуальному решению консилиума врачей. То есть фактически произошло изменение трактовки такого понятия, как "поздний аборт": если раньше прерывание беременности на поздних сроках (22-27 недель) считалось "поздним абортом", то сейчас это стало "сверхранними преждевременными родами" [Суханова 2013]. Все эти перемены в определениях прежде всего должны были отразиться и отразились на показателях перинатальной смертности и структуре рождений и смертей детей по весу. Что же происходило с перинатальной смертностью в России и какие изменения произошли в 2012 г.?

\footnotetext{
${ }^{2}$ http://www.rg.ru/2013/04/03/rozhdenie-dok.html

${ }^{3}$ Там же.

${ }^{4}$ http://www.rg.ru/2012/02/17/abort-dok.html
} 


\section{ТЕНДЕНЦИИ ПЕРИНАТАЛЬНОЙ СМЕРТНОСТИ}

Можно было ожидать, что переход на новые определения живо- и мертворождения увеличит число детей, умерших на первой неделе жизни, за счет включения в раннюю неонатальную смертность детей с массой тела ниже 1000 г, умерших, не прожив и 168 часов, которые до 2012 г. считались мертворожденными. Также ожидалось увеличение мертворождаемости, хотя и не столь высокое, как ранней неонатальной смертности: число мертворожденных должно было бы увеличиться за счет поздних абортов, но оно же должно уменьшиться за счет перехода части детей, считавшихся мертворожденными, в умершие на первой неделе жизни. В реальности показатель ранней неонатальной смертности (как части перинатальной смертности) в 2012 г. по сравнению с уровнем 2011 г. увеличился на 36\%, а мертворождаемости - на 41\%, в целом же коэффициент перинатальной смертности вырос на $39 \%$.

Посмотрим, как эти изменения выглядят на фоне динамики прошлых лет. С 1993 (год предыдущего изменения определений живо- и мертворождений в стране) по 2011 г. перинатальная смертность в России (по данным государственной статистики) снизилась в 2,4 раза (младенческая смертность - в 2,7 раза). Это снижение происходило в основном за счет ранней неонатальной составляющей, которая снизилась в 3,6 раза, в то время как мертворождаемость снизилась всего в 1,7 раза. В 1998 г. кривые, соответствующие двум компонентам ранней неонатальной смертности, пересеклись (рисунок 2) и вклад мертворождаемости в перинатальную смертность стал больше ее ранней неонатальной составляющей. В целом за период с 1993 по 2011 г. доля мертворождений выросла с 44,8 до $62,7 \%$.

Если государственная статистика начала учитывать в перинатальной смертности детей с весом 500 г и выше и сроком беременности выше 22 недель только с 2012 г., то, как уже отмечалось, отраслевая (медицинская) статистика должна была делать это, начиная с 1993 г.

Динамика показателей перинатальной смертности по данным медицинской статистики (форма 32 «Сведения о медицинской помощи беременным, роженицам и родильницам» Федерального статистического наблюдения), имеющимся в нашем распоряжении, представлена на рисунке 3. Изменения коэффициента перинатальной смертности и его составляющих для родившихся с массой тела 500 г и более с 2004 по 2012 г. можно охарактеризовать как умеренно быстрое снижение (рисунок 3, левая панель). За 8 лет перинатальная смертность в учреждениях Минздрава для детей, рожденных с весом более 500 г, снизилась в 2 раза, мертворождаемость - в 2,2 раза, а ранняя неонатальная смертность - в 1,7 раза. Соответственно, основной вклад в изменение уровня перинатальной смертности внесло снижение мертворождаемости. За 2004-2011 гг. доля мертворождений в перинатальной смертности почти не изменилась, оставаясь на уровне $3 / 4$ от всех перинатальных смертей. Только в 2012 г. доля мертворождений снизилась до 69\%. При этом в 2012 г. при переходе государственной статистики на новые определения живо- и мертворождения медицинская статистика зафиксировала резкое снижение коэффициента перинатальной смертности, которое произошло в основном за счет мертворождаемости. 


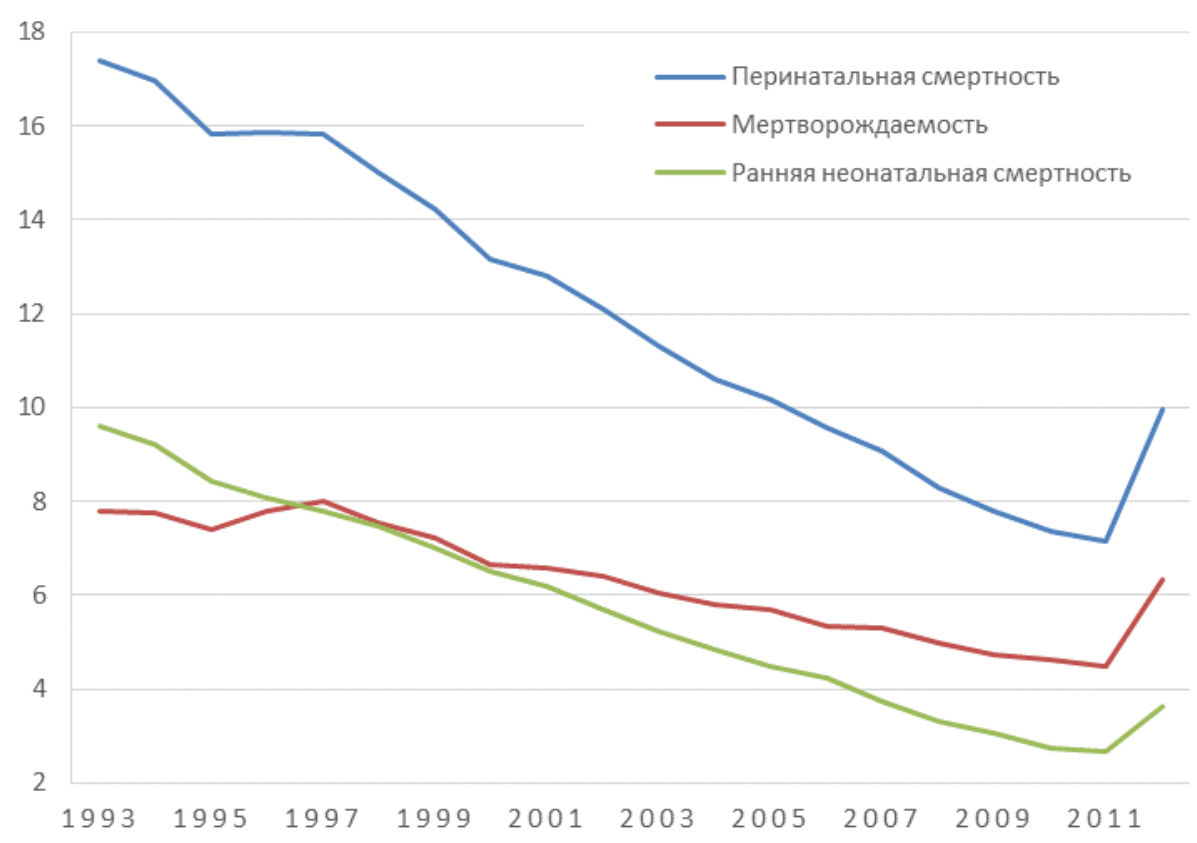

\section{Рисунок 2. Перинатальная смертность и ее составляющие в России, 1993-2012 гг., на 1000 родившихся живыми и мертвыми}

Источник: [Росстат 2013].

На правой панели рисунка 3 представлена динамика перинатальной смертности по данным медицинской статистики для детей, родившихся с весом более 1000 г, то есть по критериям, сходным с используемыми в государственной статистике до 2012 г. Соответственно и общая картина, кроме 2012 г., похожа на данные официальной статистики. Но показатели мертворождаемости в официальной статистике ниже, а ранней неонатальной и в целом перинатальной смертности заметно выше. В 2012 г. показатель мертворождаемости немного увеличился по сравнению с 2011 г., а ранней неонатальной смертности снизился. К 2012 г. по сравнению с 2004 г. снижение перинатальной смертности детей с массой тела 1000 г и более составило 29\%, в том числе мертворождаемость снизилась лишь на 19\%, а ранняя неонатальная смертность - на 45\%. 

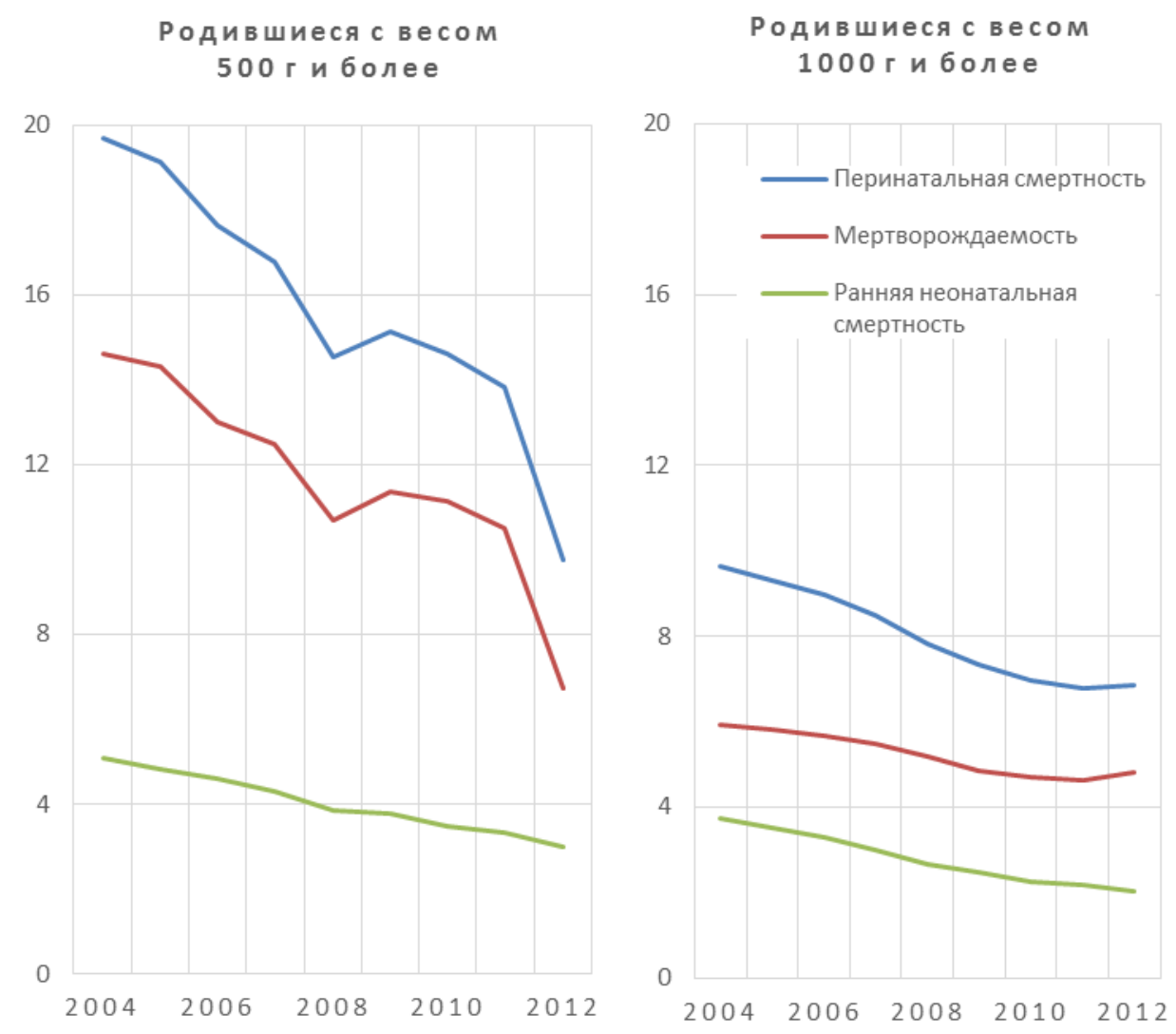

Рисунок 3. Перинатальная смертность и ее составляющие в России, 2004-2012 гг., на 1000 родившихся живыми и мертвыми (по данным медицинской статистики)

Источник: Рассчитано по данным формы 32 Федерального статистического наблюдения «Сведения о медицинской помощи беременным, роженицам и родильницам».

Рассмотрим подробнее изменения, произошедшие со смертями младенцев в перинатальный период по данным медицинской статистики за 2011-2012 гг. ${ }^{5}$ Для сравнения динамики родившихся и умерших мы использовали таблицу «Распределение родившихся и умерших по массе тела при рождении (2245)» формы 32 «Сведения о медицинской помощи беременным, роженицам и родильницам» Федерального статистического наблюдения $^{6}$ за 2011 и 2012 г. Согласно этим таблицам общее число родившихся детей с экстремально низкой массой тела (ЭНМТ), то есть с массой тела от 500 до 999 г, в 2012 г. по сравнению с 2011 г. снизилось на 36\%, при этом число живорожденных выросло на 25\%. Соответственно число мертворожденных снизилось на 65\%. То есть, общее снижение произошло именно за счет мертворожденных. В группе с весом 500-749 г общее число рождений снизилось на 46\%, а 750-999 г - на 27\% (таблица 1). Число родившихся живыми выросло в первой группе на 66\%, во второй на 11\%, а мертворожденных снизилось на 67 и

${ }^{5}$ Государственная статистика с 2011 г. собирает данные о родившихся и умерших детях не только по весу, но и по возрасту матери - таблицы Р247 и С06 статистического учета. Но, к сожалению, в 2011 г. заполняемость этих таблиц была плохой, и большая часть детей попадала в категории «неизвестный вес» и «неизвестный возраст».

6 Формы за эти годы утверждены приказом Росстата от 29.07.2009 №154 и приказом Росстата от 29.12.2011 № 520. 
$63 \%$ соответственно. Такое снижение числа мертворожденных детей, родившихся с весом до 1000 г, привело к общему большому снижению числа мертворожденных (на 32\%). Число умерших детей в ранний неонатальный период в этой весовой группе в целом снизилось на $12 \%$. Это произошло за счет детей с весом 750-999 г, среди которых число умерших снизилось на 29\%, а выросло оно только среди детей, рожденных с самым маленьким весом - 500-749 г (на 17\%). Это привело к небольшому снижению общего числа умерших в первые 168 часов в 2012 г. по сравнению с 2011 г. (на 4,2\%).

В группе детей с очень низкой массой тела (ОНМТ), т.е. с массой от 1000 до 1499 г, наблюдается обратная динамика - рост общего числа родившихся на $21 \%$, из них живорожденных на 17\% и мертворожденных на 49\%. Число детей, умерших в первые 168 часов жизни, в отличие от более маловесной группы, выросло на 19\%. При этом число умерших в ранний неонатальный период для детей, родившихся с весом 1500-1999 г, также снизилось на 19\%. То есть, при сравнении перинатальной смертности и ее составляющих по весу за 2011-2012 гг. бросается в глаза резкое улучшение этих показателей для детей с ЭНМТ и небольшой их рост у детей с ОНМТ.

Все эти изменения привели к изменению и в коэффициентах перинатальной смертности, и в их составляющих (таблица 1). У детей, родившихся с самым маленьким весом (500-749 г) коэффициент перинатальной смертности снизился на 210 пунктов промилле. Снижение произошло за счет мертворождаемости (-327 пунктов за 2011-2012 гг.). Ранняя неонатальная смертность же выросла на 117 пунктов. Для весовой группы 750999 г зафиксировано снижение перинатальной смертности (-260 пунктов) и опять за счет мертворождаемости (-256 пунктов). Соответственно зафиксировано и небольшое снижение ранней неонатальной смертности (-4 пункта). А вот в весовой группе с ОНМТ (1000-1499 г), которую изменения определения живорождения формально не затронули, перинатальная смертность немного выросла (на 24 пункта). И опять эти изменения произошли за счет мертворождаемости (+25 пунктов).

Все зафиксированные изменения в перинатальной смертности не могут быть объяснены только введением новых критериев живо- и мертворождения. По логике, изменение критериев живорождения должны были привести к росту рождений и смертей именно за счет детей, родившихся с ЭНМТ. Но данные медицинской статистки показывают, что это не совсем так. Как отмечено выше, число родившихся живыми, умерших в ранний неонатальный период жизни, в весовой группе 500-749 г увеличилось, а число мертворожденных сильно снизилось. Среди детей с весом 750-999 г при рождении выросло только число живорождений, а число мертворожденных и умерших в ранний неонатальный период снизилось. Выросло же число родившихся, умерших в ранний неонатальный период жизни, и мертворожденных среди детей, родившихся с ОНМТ. Неужели произошло что-то, влияющее на детей только с этим весом? Вряд ли, учитывая, что числа родившихся и умерших в этой весовой группе в последние годы по данным той же таблицы 2245 формы 32 меняются незначительно. 


\section{Таблица 1. Перинатальная смертность по массе тела при рождении в России в 2011-2012 гг.}

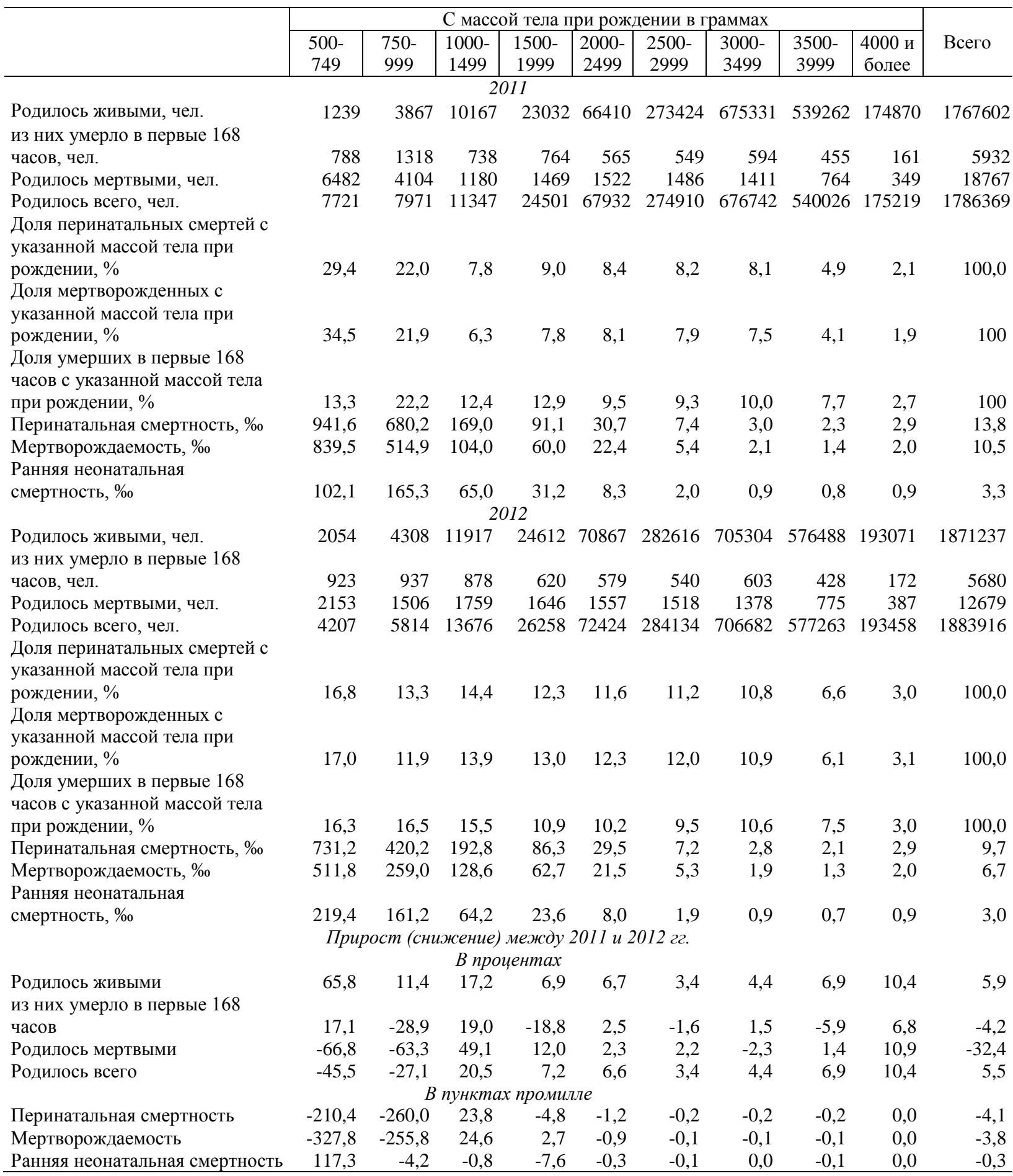

Источник: Рассчитано по данным формы 32 Федерального статистического наблюдения «Сведения о медищинской помощи беременным, роженицам и родильницам».

Еще одна особенность состоит в том, что впервые за период с 2004 г. число умерших в первые 7 дней жизни младенцев в весовой группе 1500-1999 г оказалось меньше, чем детей, родившихся с весом 1000-1499 г. 
На наш взгляд, такие изменения являются наглядным доказательством того, о чем говорили многие эксперты, а именно, существования ранее недоучета мертворожденных и умерших детей в ранний неонатальный период с массой тела немногим более 1000 г путем занижения веса ребенка и соответственно отнесения к мертворожденным или даже поздним выкидышам. С изменением критериев живорождения применительно к детям с ОНМТ подобная практика утратила смысл (так как требует существенного искажения массы тела новорожденного), отсюда и рост их доли в перинатальных смертях. В группе детей с ОНМТ стали проводить более полную регистрацию, и дети, родившиеся с массой тела немногим более 1000 г, учитываются с реальным весом при рождении. С другой стороны, резкое уменьшение числа мертворожденных в самой низкой весовой категории и рост числа абортов на сроках до 21 недели (на 20\%) говорят о том, что практика занижения массы тела не исчезла, а просто стала применяться к новорожденным с ЭНМТ. Косвенным доказательством наличия перебросов и неполной регистрации детей с ЭНМТ является то, что число всех мертворожденных по ф. 32 (12679) больше, чем по данным официальной статистики (12142) [Суханова 2013] ${ }^{7}$.

При сравнении линий на рисунках 2 и 3 (правая панель), которые вплоть до 2011 г. включительно практически характеризуют одну и ту же совокупность, нетрудно увидеть различия в темпах изменения и уровне показателей между данными Минздрава и государственной статистики. Данные о перинатальной смертности, собранные Росстатом, получены путем обработки территориальными органами государственной статистики медицинских свидетельств о мертворождении и о перинатальной смерти, заполняемых в тех же медицинских учреждениях. В данные Росстата включают также родившихся и умерших вне медицинских учреждений Минздрава России, но их число не столь велико, чтобы объяснить такие различия в уровнях показателей. Отсюда возникает логическое предположение, что часть детей, попавших в медицинскую статистику, по каким-то причинам не попадает в государственную статистику или включается в другие ее категории.

В целом, при прочих равных условиях нельзя забывать, что структура показателя перинатальной смертности и его величина во многом служат показателем качества и уровня оказания медицинской помощи беременным, роженицам и новорожденным, а также качества ведения медицинской документации. К сожалению, этот критерий не независимый. Уровень перинатальной и, особенно, ранней неонатальной смертности используется при оценке работы медицинских учреждений. Показатель младенческой смертности в регионе также учитывается при оценке работы областной администрации. Так что ухудшение показателей не выгодно никому и реальная картина уровня перинатальной смертности и ее составляющих в регионе может оказаться искаженной.

\footnotetext{
${ }^{7}$ В 2013 г. зафиксирована такая же ситуация - число мертворожденных по данным медицинской статистики (12300 чел.) больше, чем по данным официальной статистики (12226 чел.), что говорит о том, что различие 2012 г. не было случайным.
} 


\section{КОМПОНЕНТЫ МЛАДЕНЧЕСКОЙ СМЕРТНОСТИ}

Изменения определений живо- и мертворождения затрагивают, прежде всего, перинатальный период жизни ребенка. Но они влияют и на показатель смертности детей в возрасте от 7 до 28 дней (поздней неонатальной смертности), и на младенческую смертность в целом.

Как уже отмечалось, уровень младенческой смертности в России в 2012 г. вырос с 7,4 до 8,6\%. Основной рост (78\%) пришелся на раннюю неонатальную составляющую младенческой смертности. Но выросла также и поздняя неонатальная смертность (23\% общего роста). Зато постнеонатальная смертность снизилась, и ее вклад в изменение коэффициента младенческой смертности составил -1\%. Рост коэффициента поздней неонатальной смертности начался еще в 2011 г., но в 2012 г. скорость роста утроилась (рисунок 4). Этот рост может быть связан с двумя явлениями, оцениваемыми противоположным образом. Развитая медицина до последнего борется за жизнь новорожденных, в результате чего смерти, которые раньше происходили в первые дни и часы жизни, теперь отодвигаются во времени [Andreev, Kingkade 2011]. Но рост может быть связан и с недостаточным вниманием к спасенным детям со стороны системы здравоохранения после выписки из организаций системы родовспоможения.

На рисунке 4 видна еще одна особенность структуры младенческой смертности в России - довольно медленное в последние годы снижение постнеонатальной смертности, уровень которой все еще очень высок и которая остается в России важным резервом снижения младенческой смертности. За 1991-2011 гг. (то есть без учета влияния изменения определения живорождения) младенческая смертность снизилась на 10,5 в расчете на 1000 живорожденных. С ранней неонатальной смертностью связано 58\% этого снижения, с постнеонатальной - 36\% и с поздней неонатальной - только 6\%. Если же рассматривать период 1991-2012 гг., то коэффициент младенческой смертности снизился на 9,2\%о и 55\% этого снижения произошло за счет ранней неонатальной смертности, $42 \%$ - за счет постнеонтальной смертности и только 3\% (еще меньше) - за счет поздней неонатальной составляющей младенческой смертности.

По мере снижения уровня постнеонатальной смертности внимание многих международных организаций все больше акцентируется не на младенческой смертности, а на мертворождаемости, неонатальной смертности и ее компонентах, а также на смертности детей до 5 лет. В Европейском докладе о состоянии перинатального здоровья за 2010 г. приводятся данные о ранней и поздней неонатальной смертности, а также постнеонатальной смертности для стран, входящих в ЕС, и Норвегии [Euro-Peristat 2013]. Для нас большой интерес опубликованных в докладе данных определяется тем, что они приводятся для срока беременности 22 недели и выше и поэтому сопоставимы с российскими данными. 


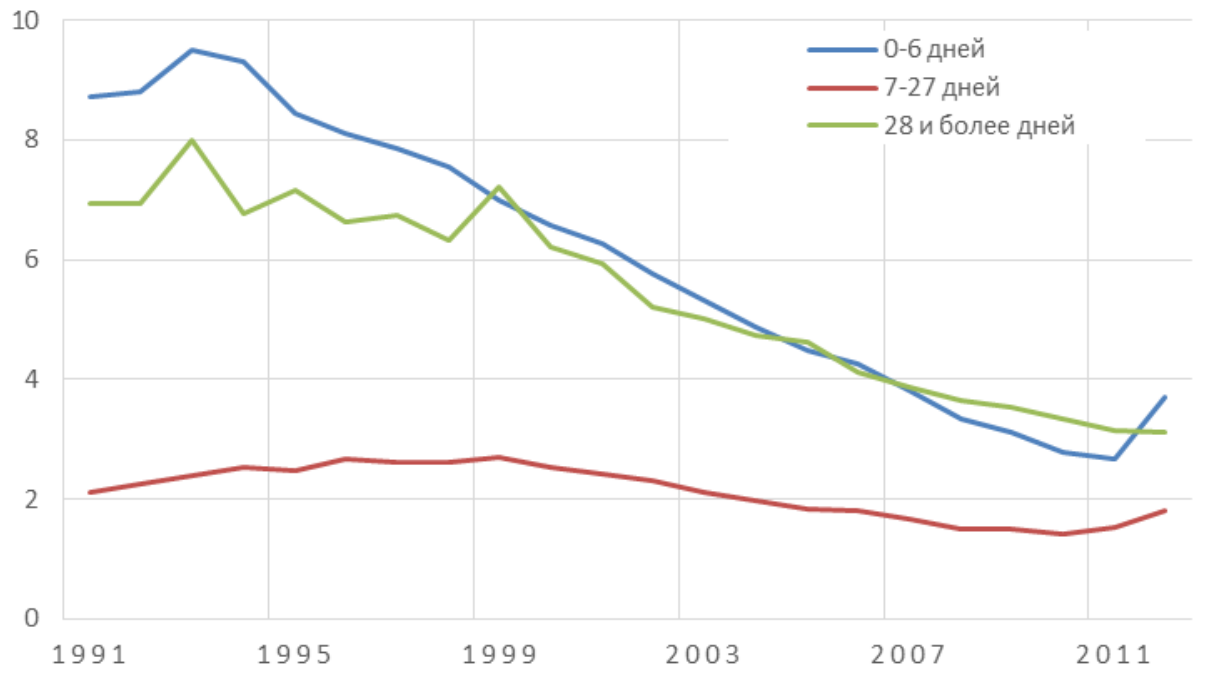

Рисунок 4. Составляющие младенческой смертности в России, 1991-2012 гг., на 1000 родившихся живыми

Источник: Расчет автора по данным государственной статистики.
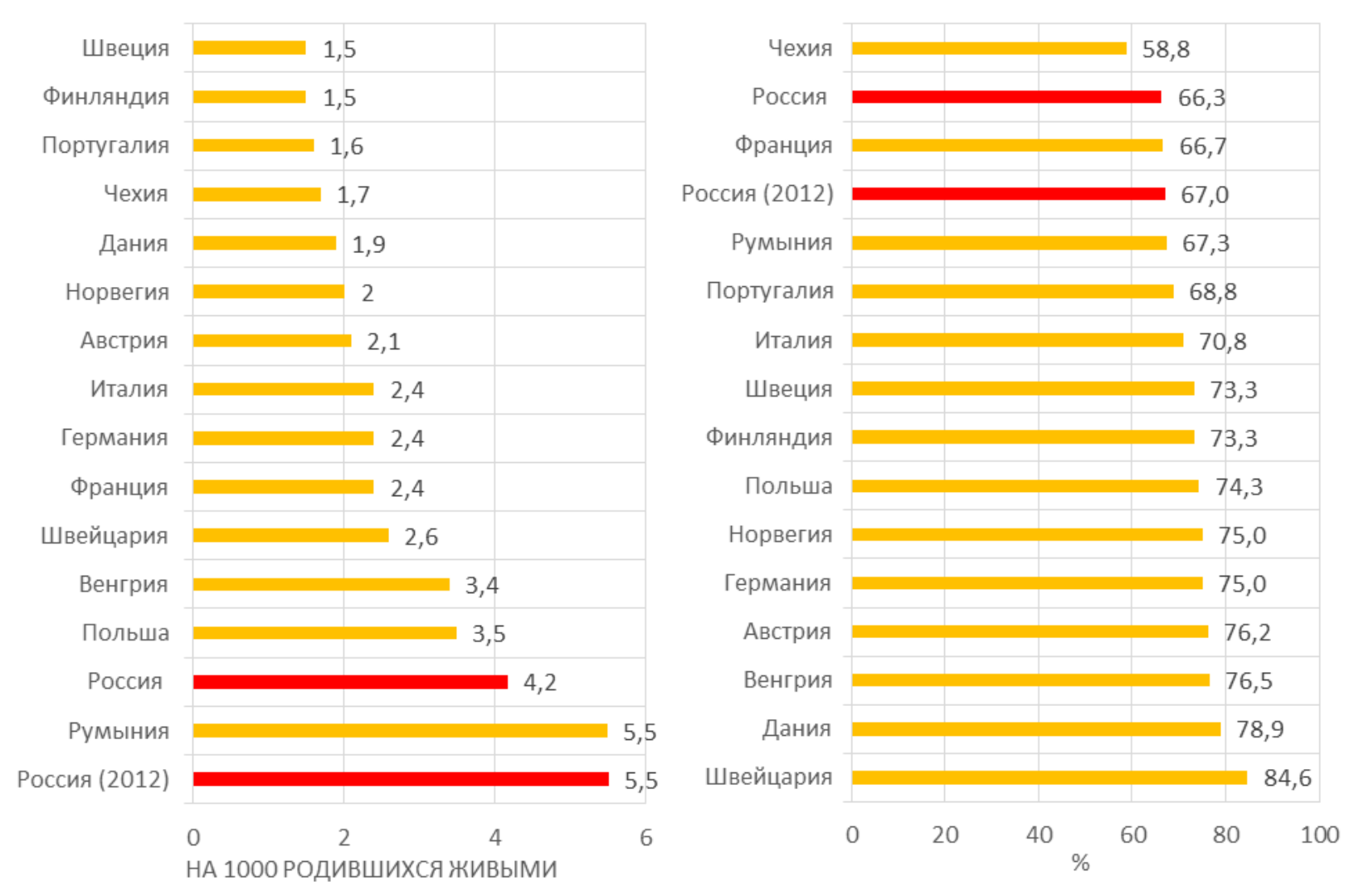

Рисунок 5. Неонатальная смертность и доля ранней неонатальной компоненты в ней в России и в ряде европейских стран в 2010 г. и в России в 2012 г.

Источник: [Euro-Peristat 2013; Poccmam 2013].

На рисунке 5 (левая панель) приведены данные об уровне неонатальной смертности в ряде европейских стран в 2010 г. и в России в 2010 и 2012 г. (то есть до и после изменения 
определения живорождения) и о доле ранней неонатальной смертности в неонатальной смертности в этих странах (правая панель). По уровню неонатальной смертности Россия в 2012 г. проигрывает всем из рассматриваемых в докладе стран, кроме Румынии, по данным за 2010 г. «выигрывает» только у той же Румынии. Таким образом, в области младенческой смертности в России далеко не все внушает оптимизм, что подтверждает и упоминавшийся выше рост постнеонатальной смертности.

\section{РЕГИОНАЛЬНЫЙ АСПЕКТ ИЗМЕНЕНИЙ МЛАДЕНЧЕСКОЙ СМЕРТНОСТИ В 2011-2012 ГГ.}

Уровни младенческой и перинатальной смертности, как и их составляющие, в целом по России включают и нивелируют изменения во всех административно-территориальных единицах страны. Как уже отмечалось, за длительный период в России в целом наблюдается устойчивая тенденция к снижению младенческой смертности. Но темпы этого снижения по регионам были различными. По-разному отразился в регионах и переход на новое определение живорождения в 2012 г. Приказ о переходе на новое определение живорождения был опубликован в «Российской газете» только 3 апреля 2012 г., лишь после этого он считался вступившим в силу. Но рост показателей младенческой смертности в ряде регионов был зафиксирован уже с начала года и шел разными темпами в течение года [Андреев, Кваша 2013]. В результате к концу года в 9 регионах младенческая смертность не выросла, а, наоборот, снизилась (рисунок 6). Наибольшее снижение отмечено в Ивановской области - более чем на $25 \%$.

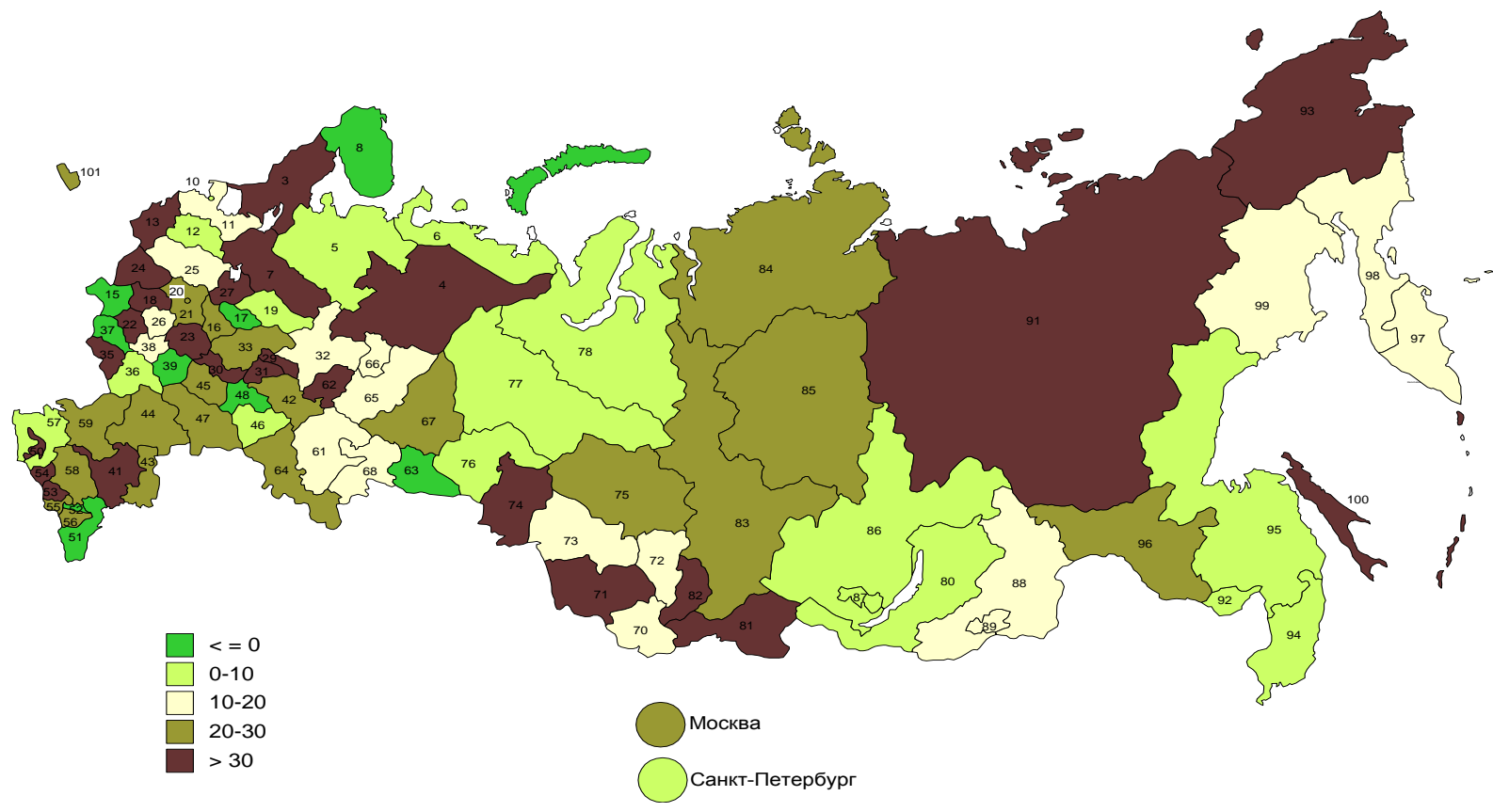

Рисунок 6. Изменение младенческой смертности в России в 2012 г. по отношению к 2011г., \%

Источник: [Росстат 2013]. 
В 13 регионах уровень младенческой смертности повысился не больше чем на 10\%. Но в большей части регионов (29) рост был выше $30 \%$.

В целом в 2012 г., как и раньше, к регионам с минимальными показателями младенческой смертности относятся Тамбовская область и г. Санкт-Петербург (4,1 и 4,5\% соответственно), а с максимальными - Чеченская Республика и Чукотский автономный округ (21,9 и 21,2\%). При этом разброс по уровню коэффициента младенческой смертности за год увеличился с 14,2 до 17,8\%.

Высказанные ранее сомнения в правильности фиксации веса новорожденных в некоторых медицинских документах основывались на неожиданных изменениях в распределении родившихся и умерших детей по массе тела при рождении. Для большинства регионов такой подход неприменим, так как сами по себе числа всех умерших, мертворожденных и родившихся детей с ЭНМТ, а также с ОНМТ очень малы. Опровергнуть или подтвердить сомнения можно только путем проверки первичной медицинской документации в регионах.

За последние годы в России в соответствии с распоряжением Правительства Российской Федерации от 04.12.07 № 1734-р было введено в эксплуатацию 22 перинатальных центра, распоряжением Правительства Российской Федерации от 09.12.13 № 2302-р утверждено строительство еще 32 перинатальных центров в 30 субъектах Федерации. На эти цели выделяют десятки миллиардов рублей. Строительство перинатальных центров производилось с учетом перехода в 2011 г. на так называемую трехуровневую систему оказания медицинской помощи беременным женщинам и новорожденным. Эти меры, наряду с другими, должны были привести к снижению младенческой смертности в регионах, где построены перинатальные центры, и в стране в целом.

Основная часть перинатальных центров введена в действие в конце 2010 - конце 2012 г., поэтому о четкой связи между их введением и изменением уровня мертворождаемости, ранней неонатальной и младенческой смертности в целом в этих регионах можно делать только предварительные выводы. Данные статистики свидетельствуют, что ввод в действие большинства перинатальных центров привел к снижению уровня перинатальной смертности, но в трех регионах (Тверская, Кемеровская, Волгоградская области) на следующий год после ввода центров он вырос. В ряде регионов, введших в эксплуатацию такие центры, на следующий год после этого выросла и младенческая смертность. При этом в части регионов, где эти центры не были построены, и перинатальная, и младенческая смертность снизились. В 2012 г. в большинстве регионов, где действуют перинатальные центры, зафиксирован рост показателей перинатальной смертности (на наш взгляд, это говорит об ответственной работе как медиков, так и медицинских статистиков этих центров).

По данным приложения к форме 32 за 2012 г. в медицинских учреждениях низового и среднего звена родилось 77\% живых детей, включая 51\% с ЭНМТ и 55\% с ОНМТ, а также $70 \%$ мертворожденных (60\% с ЭНМТ и 68\% с ОНМТ). Видимо, при всей полезности создания перинатальных центров в нашей стране с ее огромной территорией и неразвитой 
дорожной сетью всех проблем снижения младенческой смертности эти центры решить не могут и надо развивать работу медицинских учреждений низового звена по всей стране.

\section{ПО СТРУКТУРЕ ПРИЧИН СМЕРТИ МЛАДЕНЦЕВ РОССИЯ ВСЕ БОЛЕЕ ПРИБЛИЖАЕТСЯ К РАЗВИТЫМ СТРАНАМ}

Изначально снижение младенческой смертности в России, как и во всем мире, происходило в основном за счет причин экзогенного характера таких, как инфекционные и паразитарные болезни, болезни органов дыхания, органов пищеварения и некоторых других. Причины же в основном эндогенного характера (такие как врожденные аномалии, отдельные состояния, возникающие в перинатальном периоде и некоторые другие) начали вносить свою лепту в снижение младенческой смертности лишь с последней четверти прошлого века (до этого отмечался рост смертности младенцев от этих причин), но сейчас именно они все в большей степени определяют снижение или рост смертности детей до 1 года (таблица 2).

Таблица 2. Коэффициенты младенческой смертности по причинам смерти и вклад причин смерти в число умерших в возрасте до 1 года в России, 1993-2012 гг.

\begin{tabular}{|c|c|c|c|c|c|c|c|c|c|c|c|}
\hline Причины & 1993 & 1995 & 2000 & 2005 & 2006 & 2007 & 2008 & 2009 & 2010 & 2011 & 2012 \\
\hline \multicolumn{12}{|c|}{ Коэффичиенты младенческой смертности, на 10000 родившихся живыми } \\
\hline $\begin{array}{l}\text { Некоторые инфекционные } \\
\text { и паразитарные болезни }\end{array}$ & 14,2 & 12,7 & 9,2 & 5,0 & 4,1 & 3,8 & 3,0 & 2,8 & 3,0 & 2,7 & 3,1 \\
\hline Болезни системы & & & & & & & & & & & \\
\hline кровообращения & 1,3 & 1,3 & 1,2 & 1,1 & 1,1 & 1,3 & 1,0 & 1,6 & 1,3 & 0,9 & 0,6 \\
\hline и органов дыхания & 30,9 & 24,2 & 16,5 & 8,3 & 7,8 & 6,9 & 6,1 & 5,4 & 4,6 & 4,5 & 4,1 \\
\hline $\begin{array}{l}\text { Болезни органов } \\
\text { пищеварения }\end{array}$ & 1,5 & 1,1 & 0,9 & 0,7 & 0,7 & 0,6 & 0,4 & 0,5 & 0,5 & 0,5 & 0,5 \\
\hline Врожденные аномалии & 40,7 & 41,8 & 35,5 & 26,9 & 24,5 & 22,7 & 20,6 & 20,3 & 18,2 & 18,0 & 18,5 \\
\hline $\begin{array}{l}\text { Отдельные состояния, } \\
\text { возникающие в }\end{array}$ & & & & & & & & & & & \\
\hline 1 периоде & 88,0 & 78,5 & 67,7 & 49,1 & 47,3 & 42,9 & 39,3 & 36,7 & 34,5 & 34,9 & 48,1 \\
\hline Симп & & & & & & & & & & & \\
\hline болезни & 5,7 & 5,6 & 7,3 & 7,0 & 5,7 & 5,2 & 5,5 & 4,7 & 4,4 & 4,3 & 4,1 \\
\hline Други & 6,7 & 5,9 & 5,3 & 4,0 & 4,3 & 3,7 & 3,5 & 3,6 & 3,9 & 3,1 & 3,1 \\
\hline Внешн & 9,8 & 10,1 & 9,7 & 7,6 & 6,7 & 6,4 & 5 , & 5,7 & 4 & 4,6 & 4,3 \\
\hline Всего & 198,8 & ${ }^{181,2}$ & $\begin{array}{l}153,3 \\
\text { клад } n\end{array}$ & $\begin{array}{l}109,7 \\
\text { оичин с }\end{array}$ & $\begin{array}{r}102,2 \\
\text { мерти, }\end{array}$ & $\%$ & 85,2 & 81,4 & 75,1 & 73,5 & 86,4 \\
\hline $\begin{array}{l}\text { Некоторые инфекционные } \\
\text { и паразитарные болезни }\end{array}$ & 7,1 & 7,0 & 6,0 & 4,5 & 4,1 & 4,0 & 3,5 & 3,5 & 4,1 & 3,7 & 3,6 \\
\hline $\begin{array}{l}\text { Болезни системы } \\
\text { кровообрашения }\end{array}$ & 0.7 & 0.7 & 0.8 & 10 & 11 & 14 & 1 & 19 & 18 & 12 & 0.7 \\
\hline в дыхания & 15,5 & 13,4 & 10,7 & 7,5 & 7,6 & 7,4 & 7,1 & 6,6 & 6,2 & 6,1 & 4,7 \\
\hline $\begin{array}{l}\text { Болезі } \\
\text { пищег }\end{array}$ & 0,8 & 0,6 & 0,6 & 0,6 & & 0,7 & & 0,6 & 0,6 & 0,7 & 0,6 \\
\hline Врожденные аномалии & 20,5 & 23,1 & 23,1 & 24,6 & 24,0 & 24,3 & 24,1 & 25,0 & 24,2 & 24,5 & 21,4 \\
\hline $\begin{array}{l}\text { Отдельные состояния, } \\
\text { возникающие в }\end{array}$ & & & & & & & & & & & \\
\hline перинатальном периоде & 44,3 & 43,3 & 44,2 & 44,8 & 46,3 & 45,8 & 46,1 & 45,2 & 45,9 & 47,5 & 55,7 \\
\hline $\begin{array}{l}\text { Симптомы, призн } \\
\text { отклонения от ноя }\end{array}$ & & & & & & & & & & & 4,7 \\
\hline руг & 3,4 & 3,3 & 3,5 & 3, & 4, & 3 , & & 4 & 5 , & 4,2 & 3,5 \\
\hline Внешние причины & 4,9 & 5,6 & 6,3 & 6,9 & 6,6 & 6,8 & 6,9 & 7,1 & 6,3 & 6,3 & 5,0 \\
\hline Всего & 100 & 100 & 100 & 100 & 100 & 100 & 100 & 100 & 100 & 100 & 100 \\
\hline
\end{tabular}

Источник: Расчет автора по данным государственной статистики. 
В целом в 2012 г., впрочем, как и в предшествующие годы, первое место среди причин младенческой смертности в России принадлежит отдельным состояниям, возникающим в перинатальный период (смерть от которых, на наш взгляд, в части случаев - прямой брак работы системы родовспоможения), второе - врожденным аномалиям, а вот на третьем месте, начиная с 2009 г., находятся внешние причины, обогнавшие болезни органов дыхания, которые занимали это место ранее (таблица 2). В классе внешних причин основной вклад в смерть младенцев вносят такие причины, как случайное удушение и повреждения с неопределенными намерениями.

Таблица 3. Доли различных причин смерти в общем числе умерших детей в возрасте до 1 года в некоторых странах, \%

\begin{tabular}{|c|c|c|c|c|c|c|c|c|c|c|c|}
\hline Страна, год & 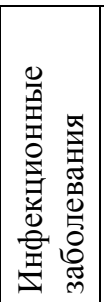 & 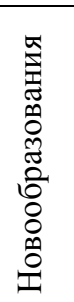 & 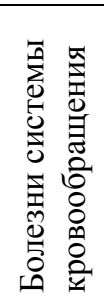 & 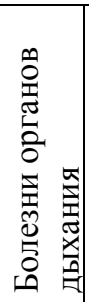 & 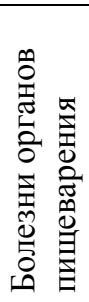 & 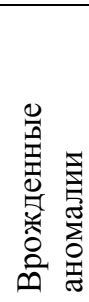 & 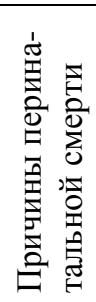 & 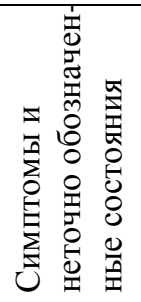 & 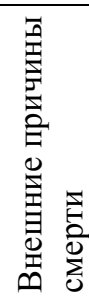 & 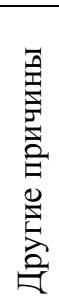 & 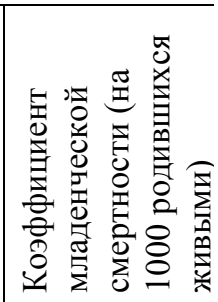 \\
\hline Белоруссия, 2009 & 5,3 & 1,2 & 1,4 & 2,7 & 0,8 & 41,1 & 26,8 & 6,8 & 6,5 & 7,4 & 4,7 \\
\hline Болгария, 2012 & 4,1 & 0,6 & 6,2 & 14,2 & 0,9 & 17,9 & 44,2 & 5,2 & 3,0 & 3,7 & 7,8 \\
\hline Великобритания, 2010 & 1,9 & 0,7 & 1,4 & 1,6 & 0,6 & 24,7 & 53,5 & 8,4 & 1,7 & 5,5 & 4,3 \\
\hline Венгрия, 2012 & 0,7 & 1,6 & 0,5 & 0,5 & 0,0 & 24,9 & 62,1 & 3,9 & 2,7 & 3,2 & 4,9 \\
\hline Германия, 2012 & 1,1 & 1,4 & 1,3 & 0,9 & 0,6 & 27,0 & 51,2 & 9,4 & 2,4 & 4,7 & 3,3 \\
\hline Италия, 2010 & 1,9 & 1,0 & 2,8 & 1,5 & 1,9 & 23,5 & 58,3 & 3,5 & 1,1 & 4,3 & 3,3 \\
\hline Казахстан, 2010 & 3,2 & 0,4 & 1,0 & 9,0 & 0,6 & 59,7 & 17,5 & 1,9 & 4,0 & 2,8 & 16,5 \\
\hline Киргизия, 2012 & 4,7 & 0,0 & 0,0 & 13,7 & 0,4 & 13,6 & 63,4 & 0,5 & 2,5 & 1,2 & 20,0 \\
\hline Молдавия, 2012 & 2,3 & 1,6 & 0,0 & 9,6 & 1,0 & 36,4 & 38,0 & 2,6 & 7,2 & 1,3 & 9,8 \\
\hline Нидерланды, 2011 & 1,4 & 0,8 & 0,9 & 0,6 & 0,8 & 30,3 & 53,1 & 3,8 & 2,4 & 6,0 & 3,6 \\
\hline Польша, 2011 & 2,0 & 1,1 & 0,6 & 2,6 & 0,1 & 34,4 & 51,8 & 4,2 & 1,9 & 1,2 & 4,7 \\
\hline Россия, 2012 & 3,6 & 0,6 & 0,7 & 4,7 & 0,6 & 21,4 & 55,7 & 5,0 & 4,7 & 2,9 & 8,6 \\
\hline Румыния, 2011 & 2,7 & 0,6 & 0,6 & 27,8 & 1,9 & 23,6 & 35,5 & 1,0 & 3,6 & 2,6 & 9,4 \\
\hline США, 2010 & 2,8 & 0,4 & 2,1 & 2,3 & 0,8 & 20,8 & 48,8 & 12,4 & 6,3 & 3,2 & 6,2 \\
\hline Украина, 2012 & 2,7 & 1,0 & 1,7 & 3,0 & 0,3 & 52,9 & 24,2 & 3,6 & 5,5 & 5,1 & 8,4 \\
\hline Чехия, 2012 & 2,8 & 0,0 & 1,8 & 1,8 & 1,4 & 22,8 & 53,0 & 5,6 & 4,6 & 6,3 & 2,6 \\
\hline Япония, 2011 & 3,8 & 1,3 & 2,8 & 5,3 & 2,3 & 35,0 & 25,2 & 12,1 & 9,0 & 3,3 & 2,3 \\
\hline
\end{tabular}

Источник: [WНО 2014b; Национальный статистический... 2013].

До 2009 г. в России отмечался рост уровня и вклада смертности младенцев от болезней системы кровообращения, который происходил за счет таких причин, как легочное сердце, внутримозговые и другие внутричерепные кровоизлияния и, в основном, такой собирательной причины, как другие причины болезней сердца, в которой, как известно, может находиться любая причина смерти от болезней системы кровообращения. Интересно, что большая часть смертей младенцев от болезней системы кровообращения приходится на постнеонатальный период жизни. И хотя вклад этого класса причин в общую смертность невелик, не обращать на это внимание нельзя. Тревожат и остающиеся до сих пор высокими, особенно при сравнении с развитыми странами, показатели смертности от инфекционных и паразитарных болезней (таблица 3). Что касается изменений за 2011-2012 гг., то за этот год больше всего выросла смертность от отдельных состояний, возникающих в перинатальном периоде (а доля, приходящаяся на эти причины, превысила 50\%), и врожденных аномалий. И это было вполне ожидаемо. Но в 2012 г., как и в предыдущие три года, продолжила рост смертность от инфекционных и паразитарных заболеваний, и это 
тревожный звонок, так как уровень смертности от этих причин характеризует, прежде всего, состояние медучреждений и медицинского обслуживания женщин и детей.

Во всех развитых странах для структуры причин смерти в возрасте до 1 года в начале XXI века характерно преобладание причин, связанных с перинатальным периодом и врожденными аномалиями, то есть причинами в основном эндогенного характера (таблица 3). В России, особенно после перехода на новое определение живорождения, эта доля стала примерно такой же, как и во многих развитых странах.

Но сохраняются и отличия. Довольно высокой в России, как и в Японии и ряде стран бывшего социалистического лагеря, остается доля, приходящаяся на внешние причины, причем, большая часть (в Японии 45\%, в России 54\%) умерших от внешних причин детей до 1 года приходится на случайные удушения. Также в основном для стран бывшего СССР и Японии характерна более высокая доля умерших от инфекционных и паразитарных болезней.

\section{ЛИТЕРАТУРА}

Андреев Е.М., Е.А. Кваша (2013). Новый счет младенческой смертности: предварительные итоги // Демоскоп-Weekly. №541-542. URL: http://demoscope.ru/weekly/2013/0541/analit05.php (дата обращения: 15.04.2014).

Андреев Е.М., Е.А. Кваша, Т.Л. Харькова (2013). Резервы снижения младенческой смертности использованы не полностью. // Население России 2010-2011 /Под. ред. А.Г. Вишневского. М.: Издательский дом ВШЭ: 404-419.

Национальный статистический комитет Кыргызской Республики (2013). Демографический ежегодник Кыргызской Республики: 2008-2012 (2013). Бишкек: Национальный статистический комитет Кыргызской Республики. URL: http://stat.kg/images/stories/docs/tematika/demo/demography\%20yearbook\%2020082012.pdf (дата обращения: 15.04.2014).

Росстат (2013). Демографический ежегодник России, 2013. Стат. сб. М.: Росстат. URL: http://www.gks.ru/bgd/regl/B13_16/Main.htm (дата обращения: 15.04.2014).

Суханова Л.П. (2013). Исходы беременности и перинатальные потери при новых критериях рождения // Социальные аспекты здоровья населения. № 3. URL: http://vestnik.mednet.ru/content/view/483/30/lang,ru/ (дата обращения: 15.04.2014).

Andreev E. M., W.W. Kingkade (2011). Average age at death in infancy and infant mortality level: reconsidering the Coale-Demeny formulas at current levels of low mortality // MPIDR Working Paper WP-2011-016. - 23 p.

Euro-Peristat (2013). European Perinatal Health Report. Health and Care of Pregnant Women and Babies in Europe in 2010. Euro-Peristat. URL: http://anrdpn.vjf.cnrs.fr/sites/default/files/European\%20Perinatal\%20Health\%20Report_2010.pdf (дата обращения: 15.04.2014).

WHO (2014a). European health for all database (HFA-DB). World Health Organization Regional Office for Europe. http://data.euro.who.int/hfadb/ (дата обращения: 15.04.2014).

WHO (2014b). WHO Mortality Data base. World Health Organization. URL: http://www.who.int/whosis/mort/download/en/index.html (дата обращения: 15.04.2014) 


\title{
MORTALITY OF CHILDREN UNDER 1 YEAR OLD IN RUSSIA: WHAT HAS CHANGED AFTER THE TRANSITION TO THE NEW DEFINITION OF LIVE BIRTH AND STILLBIRTH
}

\section{EKATERINA KVASHA}

Ekaterina A. Kvasha, Institute of Demography, National Research University Higher School of Economics. E-MAIL: ekvasha@hse.ru.

DATE RECEIVED: APRIL 2014.

\begin{abstract}
Infant mortality in Russia has been decreasing for several decades. But in 2011 Russia's infant mortality rate reached a level (7.4 per 1000 live births) more than three times higher than in countries with minimal levels. In April 2012, Russia adopted new definitions of live and stillbirths, which are much closer to the corresponding WHO definitions than those used before.
\end{abstract}

The transition to these new definitions was meant to increase the rates of perinatal, early neonatal and infant mortality in general for children weighing up to 1000 grams - those concerned by the changed definition.

This paper analyzes the changes in the structure and dynamics of death in children under 1 year of age since the transition to the new definitions of live and stillbirths, according to birth weight and period of death based on official and medical statistics. It looks at the possibility of distortion of both infant and perinatal mortality and their components.

Particular attention is given to an analysis of the structure of infant mortality by age and cause of death in Russia in comparison with other countries. Also studied is the regional aspect of changes in infant mortality for 2011-2012.

The analysis is based on data from official and medical statistics.

Key words: stillbirth, early neonatal mortality, infant mortality, causes of death, definition of live and stillbirths, infant weight.

\footnotetext{
* The study Was Implemented in the framework of the Basic Research Program at the National Research UNIVERSITY HigHER SCHOOL OF ECONOMICS (HSE) IN 2013-2014.
}

\section{REFERENCES}

Andreev E. M., W.W. Kingkade (2011) Average age at death in infancy and infant mortality level: reconsidering the Coale-Demeny formulas at current levels of low mortality // MPIDR Working Paper WP-2011-016. - 23 p.

Andreev E. M., E.A. Kvasha (2013) Novyj schet mladencheskoj smertnosti: predvaritel'nye itogi [New records of infant mortality: preliminary results] // Demoscope Weekly. № 541-542. URL: http://demoscope.ru/weekly/2013/0541/analit05.php (accessed: 15.04.2014).

Andreev E. M., E.A. Kvasha, T.L. Kharkova (2013). Rezervy snizheniya mladencheskoj smertnosti ispol'zovany ne polnost'yu [Reserves of infant mortality reducing are used not completely]. // Naselenie Rossii 2010-2011. [Population of Russia 2010-2011.] Vishnevsky A.G., ed. Moscow: HSE Publishing House: 404-419. 
Euro-Peristat (2013). European Perinatal Health Report. Health and Care of Pregnant Women and Babies in Europe in 2010. Euro-Peristat. URL: http://anrdpn.vjf.cnrs.fr/sites/default/files/European\%20Perinatal\%20Health\%20Report_2010.pdf (accessed: 15.04.2014)

Nacional'nyj statisticheskij komitet Kyrgyzskoj Respubliki (2013) [National Statistical Committee of the Kyrgyz Republic (2013)] Demograficheskij ezhegodnik Kyrgyzskoj Respubliki: 2008-2012 [Demographic Yearbook of the Kyrgyz Republic: 2008-2012]. Bishkek. National Statistical Committee of the Kyrgyz Republic. URL: http://stat.kg/images/stories/docs/tematika/demo/demography\%20yearbook\%2020082012.pdf (accessed: 15.04.2014)

Rosstat (2013). Demograficheskij ezhegodnik Rossii, 2013 [Demographic Yearbook of Russia, 2013]. Statisticheskij sbornik [Statistical issue]. Moskva: Rosstat. URL: http://www.gks.ru/bgd/regl/B13_16/Main.htm (accessed: 15.04.2014)

Sukhanova L.P. (2013) / Ishody beremennosti i perinatal'nye poteri pri novyh kriterijah rozhdenija [Pregnancy outcomes and perinatal losses in the context of new birth criteria] // Social'nye aspekty zdorov'ja naselenija [Social aspects of health]. № 3. URL: http://vestnik.mednet.ru/content/view/483/30/lang,ru/ (accessed: 15.04.2014).

WHO (2014a). European health for all database (HFA-DB). World Health Organization Regional Office for Europe. http://data.euro.who.int/hfadb/ (accessed: 15.04.2014).

WHO (2014b). WHO Mortality Data base. World Health Organization. URL: http://www.who.int/whosis/mort/download/en/index.html (accessed: 15.04.2014). 